Louisiana State University LSU Digital Commons

Faculty Publications

Department of Geography \& Anthropology

2010

\title{
In the Shadow of Slavery: Africa's Botanical Legacy in the Atlantic World
}

Andrew Sluyter

Louisiana State University, asluyter@lsu.edu

Follow this and additional works at: http://digitalcommons.lsu.edu/geoanth_pubs

Part of the Anthropology Commons, and the Geography Commons

\section{Recommended Citation}

Sluyter, Andrew, "In the Shadow of Slavery: Africa’s Botanical Legacy in the Atlantic World" (2010). Faculty Publications. 28. http://digitalcommons.lsu.edu/geoanth_pubs/28

This Article is brought to you for free and open access by the Department of Geography \& Anthropology at LSU Digital Commons. It has been accepted for inclusion in Faculty Publications by an authorized administrator of LSU Digital Commons. For more information, please contact gcoste1@lsu.edu. 
addresses its nature as a distinct place, especially in drawing out processes of fragmentation and marginalization. But in contrast to the balanced, sympathetic ethnographies, the conceptual claims are more strident, deterministic, and exclusive, especially in with respect to issues of political economy, evidenced, for example, in Widick's casual pejorative comments regarding private property rights. The 'straightforward' empirical descriptions of conflicts tend to lead to rather sweeping and at times opaque criticisms of capitalism as a whole without much attention to questions of social choice. Possibly the idea of social evolution should be given more attention. Alternatively, the book's objectives might have focused more explicitly on understanding the contemporary crisis over the redwood forests in Humboldt County. As Humboldt continues to change, social imaginaries will doubtless be shaped by past conflicts (and routines), but they will also involve new beliefs and attitudes, not least by an influx of residents with no connection to the locality's past. In the intertwining of history and geography, which is more powerful?

In summary, Trouble in the Forest is a provocative contribution to the growing literature on resource wars. If its reliance on culture theory will perhaps repel some readers, the ethnographical research is rich and detailed, and the use of crises as focusing points of social as well as economic analysis an effective starting point for interpreting the nature of evolution. Perhaps there is also a need for alternative theoretical interpretations of resource wars to more explicitly engage with and possibly draw upon one another?

Roger Hayter Simon Fraser University, Canada

doi:10.1016/j.jhg.2010.05.008

Judith A. Carney and Richard N. Rosomoff, In the Shadow of Slavery: Africa's Botanical Legacy in the Atlantic World. Berkeley, University of California Press, 2009, xvi + 280 pages, US\$27.50 hardcover.

In the Shadow of Slavery will doubtlessly become as influential as Carney's Black Rice: The African Origins of Rice Cultivation in the Americas (Harvard University Press, 2001), albeit for a quite different reason. Black Rice draws on a diversity of primary sources, from texts and illustrations to fieldwork and oral history, to argue for a leading African role in establishing the cultivation of a single crop in the Americas - one that became a major agricultural commodity. Praised as a major geographical contribution to the interdisciplinary field of Atlantic Studies, Black Rice has also received the sort of sharp criticism that academics reserve for influential publications, most tellingly the critique by David Eltis, Philip Morgan, and David Richardson in the December 2007 issue of the American Historical Review and the ensuing exchange between them and S. Max Edelson, Gwendolyn Midlo Hall, and Walter Hawthorne in the February 2010 issue of the same journal.

In contrast, In the Shadow provides a broad overview of the African role in the establishment of many crops in the Americas, most of which have never attained the commodity status of rice. Rice, in fact, occupies only a small part of In the Shadow, not even enough to justify direct engagement with the debate over Black Rice. Yet In the Shadow does demonstrate the significance of Africans in the process through which diverse actors mobilized a multitude of botanical materials and ideas along dynamic networks that intersected in particular places and times to create the novel social and environmental relations of the colonial Americas. In the Shadow does, therefore, indirectly addresses those critics of Black Rice who cannot believe that enslaved blacks could possibly have played any role in the formation of American places beyond unknowledgeable, uncreative forced labor.

Each of the chapters addresses a key aspect of that hemispheric process, with the first two taking a long-term perspective to understand African agriculture prior to the establishment of the Atlantic slave trade. Chapter one provides an account of the plants and animals that Africans domesticated, including such notables as coffee, rice, oil palm, sorghum, and the donkey. A comprehensive tabulation of the plants alone sprawls across two full pages (pp. 20-21). The second chapter treats the networks through which Africans exchanged some of those domesticates with Europeans and Asians, and vice versa, prior to the sixteenth century. For example, the Arabs and their Berber armies who conquered Iberia in the eighth century introduced sorghum into southern Spain, and traders who sailed the Indian Ocean introduced Asian bananas into Africa as well as African sorghum into Asia even earlier. The case of the banana makes an essential point: even though botanists classify it as an Asian domesticate, Africans had incorporated it into their agriculture and cuisine for centuries before carrying it with them on their Atlantic diaspora, and Carney credits its establishment in the Americas to those African agents rather than the Europeans that orthodox accounts credit with bringing it directly from Asia.

The next seven chapters concern the transfer of African botanical materials and ideas to the Americas as part of an Atlantic World that began to emerge in the late fifteenth century. Early impacts on African agriculture concern chapter three, including the demand for African crops such as rice to provision the slave trade, and the introduction of maize and manioc from the Americas into Africa for the same purpose. The next chapter deals with the slave voyages themselves, showing how, despite the importance of maize and manioc in victualling the vessels, they also carried the African 'seeds, tubers, and the people who valued them to the Americas' (p. 66). Chapter five treats the agriculture of escaped slaves, from the quilombos of Brazil to the Maroons of the Guianas, a key aspect of the entire process because those communities had some latitude to grow crops they chose in ways they wanted. Next, 'The Africanization of plantation food systems' demonstrates how Africans became 'custodians of the Amerindian botanical heritage' (p. 112), particularly in places such as Caribbean islands where colonization extirpated native peoples, and how blacks thereby became critical innovators in creating hybrid cuisines that incorporated African, European, and native American elements. Chapter seven argues for the importance of slave gardens, or provision grounds, as botanical staging areas in the overall process. 'Guineas's plants and European empire' then addresses how some African crops became colonial commodities, with planters' capitalizing on slaves' knowledge and botanical heritage as well as labor, and therefore briefly revisits Black Rice. The penultimate chapter switches the focus from plants to animals, albeit in conjunction with pasture grasses as a dominant theme, to argue that Africans contributed much to the establishment of livestock herding in the Americas.

The final chapter, 'Memory dishes of the African diaspora', serves as a conclusion by emphasizing that understanding the role of Africans in the trans-Atlantic exchange of botanical and zoological materials and ideas represents recovery of a fundamental aspect of the history of the African diaspora. It not only has intrinsic significance but informs understanding of other aspects. Some are fairly obvious, such as the relationships between cuisine, ethnic identity, and social memory. Other are much less so, such as the elemental role of African foods and cropping in social relations involving gender, class, and ethnicity.

The University of California Press has produced a beautiful book from the fonts to the some fifty illustrations. Few copyediting errors 
mar the text other than the erroneous use of 'understated' instead of overstated (p.178) and nearly verbatim repetition of a discussion of hurricanes and root crops (pp. 112 and 118).

Many will bemoan the brevity, however. The ten chapters cover a mere 180 pages, somewhat overbalanced by the some ninety pages of endnotes, bibliography, and index, as wonderful as those appurtenances might be. Most readers will want more of this engaging book but will also understand that the long neglect of this topic necessitates that many places such as Mexico and themes such as fishing do not make an appearance. Yet such regional and thematic lacunæ merely emphasize how anyone questing about for an interesting and significant research problem will find no better starting point than this book.

Andrew Sluyter Louisiana State University, USA

doi:10.1016/j.jhg.2010.05.012

Robin A. Butlin, Geographies of Empire: European Empires and Colonies c. 1880-1960. New York, Cambridge University Press, 2009, xviii + 673 pages, US\$54 paperback.

For reasons that remain murky to me, there has been a veritable explosion of interest in the geographical characteristics of European colonialism over the past twenty years or so, particularly among British geographers. As much of the writing is in a self-consciously 'critical' mould, it is difficult to put this down to the parallel nostalgia for at least the British version of colonialism on numerous recent $\mathrm{BBC}$ programmes and in the writings of conservative historians like Niall Ferguson. I think some of it, if only more recently, is owed to a reaction against the enthusiasm for joining US imperial adventures on the part of contemporary British governments enthralled by 'punching above their weight' in world politics, as the popular boxing metaphor would have it, by recapitulating and putting into practice an older colonial mentality. Much more, it seems to me, is owed to a disciplinary self-discovery of how actively involved our geographical forebears were in the colonial enterprise.

Whatever the precise reason for the new focus on late nineteenth- and early twentieth-century colonialism, however, there has been a wide-ranging re-encounter with broader theoretical issues relating to colonialism, the nature of the colonial 'experience' particularly from the 'native' point of view, and the specifics of colonial imaginations and the practices associated with attempted realizations. Geographies of Empire is an outstanding synthesis of much of the recent literature particularly adept at both showing how much geographers were involved in colonial activities and in describing the broad theoretical and empirical dimensions of the workings of European colonialism. The chapters move progressively from a discussion of concepts and frameworks for thinking about colonialism and empire through a series of rich empirically focused chapters on population movements and settlement, land expropriation, exploration and geographical knowledge and the role of geographical societies in encouraging and justifying colonialism, to more thematic chapters on the mapping of empires, colonial 'civilizing' missions, environmental transformations, transport and communications, urbanization, the economic geography of empire, and decolonization.

Particularly notable, in my view, are the chapters on geographical societies, mapping empires, and transport and communications. More generally, Robin Butlin's masterful command not only of secondary theoretical sources but also of the myriad empirical details of the colonial enterprise across eight different empires and numerous continents is astounding. I think that the move beyond the British and French cases to consider in almost equivalent detail most of the European states that ever had colonial empires is one of the most important contributions of the volume. The author's ability to retain the reader's attention across almost 700 pages of excellent prose and many useful maps and illustrations is also well worth mentioning. A book of this type could easily have become a book of lists or a simple exegesis of more original works. This is a synthesis that truly marks out an intellectual territory that will repay traversal by those with more specific interests.

Inevitably with a work of this scope, there are points of contention. For me, one concerns the selection of the works of Cole Harris and Donald Meinig in the theoretical chapter in a section on 'imperial landscapes.' I cannot say that after reading the entire book I understand the purpose of including this discussion, other than that the works of these two are important statements by historical geographers about the course of colonial settlement in North America. The relevance to the broader issue of colonialism as adumbrated in the rest of the book remains elusive. Likewise from the theoretical chapter, the discussion of 'imperialism' and 'colonialism' tends to rehearse issues, about 'gentlemanly capitalism,' 'imperialism as the highest form of capitalism' and so on, that hardly figure at all in the rest of the book. A crisper focus on the ways in which different 'waves' of colonialism, from the Portuguese to the Belgian, perhaps, had differing narratives and consequences associated with them, might have served the rest of the book better than the presently predominant cause-seeking arguments about whether this or that 'factor' was determinant. The understandable resistance to extending the book to cover the US and Russian cases also makes some of the more general arguments made at the outset without much by way of contemporary justification for the notion that we live in a 'colonial present' beyond a wink and a nod to translatio imperii. Finally, perhaps some greater engagement with works placing European colonialism within a critical geopolitical frame of reference, beyond the brief conspectus on Wallerstein's worldsystems theory, would have given the book something more of its own theoretical framework. At the moment the theoretical overview at the beginning and the richly empirical chapters that constitute the body of the book are at something of odds with one another.

I would hate to end on a negative note. This is a work of deep learning about and an obvious familiarity with a vast literature on the historic course of European colonialism from the medieval period to the recent past. The book is clearly organized and extremely well written. It will pay reading by all those with even the slightest interest in the historical geography of European colonialism and its continuing effects around the world into the present day. I see little possibility any day soon of a book's appearing that will challenge this one as the essential synthetic survey of its subject. That can be said of very few books indeed.

John Agnew University of California, Los Angeles, USA

doi:10.1016/j.jhg.2010.05.016

Ashwini Tambe, Codes of Misconduct: Regulating Prostitution in Late Colonial Bombay. Minneapolis, University of Minnesota Press, 2009, xxviii + 179 pages, US $\$ 22.50$ paperback.

This book on the regulation of prostitution in colonial Bombay contains much that is relatively familiar to historians of the policing of prostitution and sex work. Professor Tambe's 